\title{
IDENTIDADE PROFISSIONAL DA ENFERMEIRA GESTORA DO PROGRAMA DE INTEGRAÇÃO DOCENTE- ASSISTENCIAL (1978 - 2015)
}

Tese apresentada ao Programa de PósGraduação em Gerenciamento em Enfermagem (PPGEn) da Escola de Enfermagem da Universidade de São Paulo para obtenção do título de Doutora em Ciências

Área de Concentração: Gerenciamento em Enfermagem

Orientador: Prof. Dr. Genival Fernandes de Freitas

\section{SÃo PAULO}


Silva TA. Identidade profissional da enfermeira gestora do Programa de Integração Docente-Assistencial (1978 - 2015). [tese]. São Paulo: Escola de Enfermagem, Universidade de São Paulo; 2019.

\section{RESUMO}

Introdução: As profissões são estudadas e analisadas na área de Sociologia das Profissões desde os anos trinta do século XX. No contexto de inúmeras mudanças no cenário do trabalho e das profissões, avistam-se transfigurações ao longo da história no que concerne ao campo do saber da Enfermagem. Estudos têm apontado para a problemática da Identidade Profissional em todos os campos das práticas e dos saberes, inclusive no ramo da Enfermagem. Dessa forma, dedicar um novo olhar para a historiografia da referida área, na perspectiva das gerentes do Departamento de Enfermagem do Hospital Universitário da Universidade de São Paulo (DE/HU-USP) e da Divisão de Enfermagem do referido hospital (DIE/HU-USP), no contexto do Programa de Integração Docente-Assistencial (IDA) entre o Hospital Universitário da USP (HU-USP) e a Escola de Enfermagem da USP (EEUSP), permite articular 0 passado com o presente e tecer o futuro na tentativa de compreender aspectos relacionados à identidade profissional da enfermeira gestora nesse campo. Objetivos: Descrever como ocorreu a inserção profissional das enfermeiras que atuaram como gestoras do Departamento e da Divisão de Enfermagem do HU-USP no campo da integração da Escola de Enfermagem da USP com o HU-USP, no período de 1978 a 2015; Conhecer e compreender as percepções e significados atribuídos à identidade do ser enfermeira pelo grupo social que atuou como gestor do Departamento e da Divisão de Enfermagem do HU-USP, no período de 1978 a 2015; Analisar as influências e interesses políticos, sociais, econômicos e culturais que perpassaram a atuação das enfermeiras gestoras do Departamento e da Divisão de Enfermagem do HU-USP, ao fazerem a integração entre a EEUSP e o HU-USP, referente ao campo de práticas gerenciais, de ensino e de assistência à coletividade. Método: Trata-se de um estudo de natureza histórico-social, qualitativo, exploratório, pautado no método da História Oral Temática. Foram utilizadas fontes documentais para a triangulação de dados empíricos, juntamente com entrevistas semiestruturadas realizadas com onze participantes. As entrevistas foram trabalhadas com fulcro na Análise do Discurso e analisadas à luz do referencial teórico de Claude Dubar. Resultados: Emergiram 13 temas, a saber: Percepção do cuidado; Enfermagem como segunda opção; Gestão; Assistência; Postura Rígida; Articulação; Cuidado; Integração Docente-Assistencial e ensino; Poder político, centralizador e autoritário; Modelo-referência; Papel do docente/gestor; Reconhecimento; Respeito. Estes temas possibilitaram conhecer e compreender as matizes identitárias das participantes da presente pesquisa no âmbito comunitário (cultural), societário (estatutário), reflexivo ou narrativo, portanto, foi possível observar o movimento entre as transações subjetivas (biográficas) e as transações objetivas (relacionais), que permitiram a manifestação de discursos pautados nas vivências, nas aspirações, nos personagens, nas ideologias, nas idealizações e na cultura do grupo pesquisado. Conclusão: Conclui-se que o processo de construção da identidade profissional vai ao encontro da ideia que o sujeito tem sobre si e sobre o outro. É um constante ciclo, muitas vezes, efêmero, no qual ocorrem as metamorfoses identitárias.

PALAVRAS-CHAVE: Enfermagem. Identidade profissional. Papel do Profissional de Enfermagem. Enfermeiro e Enfermeira. História da Enfermagem. Serviços de Integração Docente-Assistencial. 


\section{PENSANDO A TRAJETÓRIA PROFISSIONAL E JUSTIFICATIVA DA INVESTIGAÇÃO}

A escolha profissional da pesquisadora pela Enfermagem ocorreu por volta do ano 2005, quando esta iniciou o curso de Auxiliar e de Técnico de Enfermagem em uma instituição de ensino profissionalizante. Durante a trajetória dos cursos anteriormente citados, encantou-se pela Enfermagem e decidiu prestar vestibular para graduar-se na área.

A óptica sobre a identidade da enfermeira, durante a realização do curso profissionalizante e a inserção na graduação era permeada por uma visão totalmente diferenciada, que, posteriormente, veio a desenvolver após sua inclusão no mercado de trabalho. Desta forma, mediante suas experiências e vivências referentes à socialização no campo de trabalho, percebeu a necessidade de desvelar o ser enfermeira, pois, muitas vezes, quando atuou como técnica de enfermagem, por exemplo, foi confundida com a enfermeira. Mesmo após ter finalizado a graduação e ter atuado brevemente na área, entendeu que esse profissional era pouco valorizado na sociedade. Face a essa realidade, a pesquisadora indagou-se: Por que isso acontece? Quais os fatores sociais, políticos e econômicos que podem estar envolvidos na constatação do trabalho "desvalorizado" da enfermeira ${ }^{1}$ no Brasil?

Pontua-se que, durante sua formação na graduação em Enfermagem, a pesquisadora observara que 0 trabalho da enfermeira não tinha 0 devido reconhecimento social, ainda que tivesse aprendido que o ser enfermeira estava imbricado às atitudes éticas, técnicas e científicas, que a legitimação da profissão estava envolvida por uma lacuna longínqua que separava a enfermeira como profissional e a essência do ser humano.

Durante o percurso na graduação, diversos docentes exerceram influências sobre a pesquisadora durante o processo de socialização como enfermeira. Muitos deles tornaram-se referência para que ela desempenhasse o seu trabalho profissional de forma digna e confiante.

\footnotetext{
1 Optou-se utilizar o gênero feminino, enfermeira, por duas razões: o quantitativo de mulheres na profissão de Enfermagem beira $85 \%$, segundo pesquisa realizada pelo Conselho Federal de Enfermagem e Fundação Oswaldo Cruz, em 2015; a segunda razão é porque todas as colaboradoras no presente estudo são mulheres.
} 
Nessa caminhada, foi conduzida a lecionar para graduandos de Enfermagem em uma Instituição de Ensino Superior (IES) privada do município de São Paulo. Nela, lecionou a disciplina de Gestão em Enfermagem e se deparou com dilemas dos alunos acerca do papel do enfermeiro gestor e, também, do enfermeiro docente. A partir deste fato, procurou compreender as diversas facetas que sondavam a identidade profissional da enfermeira, respaldando-se em obras que retratavam o tema.

Em vista das lacunas acerca da temática, contudo, buscou desenvolver uma pesquisa durante o Mestrado sobre a identidade do ser enfermeira. Na ocasião, destacaram-se aspectos relevantes da pesquisa sobre a identidade da enfermeira como uma profissional, imprescindível aos cuidados à saúde do indivíduo, mas igualmente com muitos desafios no tocante ao reconhecimento e valorização da referida profissão. Outro ponto destacado foi referente à escolha profissional, cujos resultados se traduziram, por razões idealistas, altruístas ou religiosas, por boa parte dos participantes do estudo; por outro lado, observou que a escolha profissional era pautada em vivências familiares no campo da saúde.

Na pesquisa durante o Mestrado, ainda, os dados coletados foram analisados segundo o referencial teórico de Claude Dubar (Dubar, 2005, 2009), que trata das nuances identitárias profissionais. Desse modo, o referencial permitiu obter subsídios e desvendar as percepções e significados do ser enfermeira, na perspectiva dos graduandos de Enfermagem daquela IES.

A proposta investigativa atual tem como objeto a identidade profissional da enfermeira gestora, inserida na Integração Docente-Assistencial (IDA), como modeloreferência estabelecido entre a Escola de Enfermagem da Universidade de São Paulo (EEUSP) e o Hospital Universitário da Universidade de São Paulo (HU-USP), no período de 1978 a 2015, para conhecer e compreender as trajetórias profissionais e a identidade profissional daquelas gerentes, utilizando, inclusive, os elementos teóricos de Claude Dubar (Dubar, 2005, 2009).

O interesse pela temática advém do interesse pela experiência que as enfermeiras, participantes do presente estudo, têm quanto às percepções e compreensões sobre os significados do ser enfermeira por serem docentes da EEUSP e gestoras de uma unidade de ensino e assistência da Universidade de São Paulo. O tripé deste conhecimento se apoia no ensino, pesquisa e extensão de serviços comunitários no Hospital Universitário. 
A trajetória profissional da pesquisadora, levou-a a desenvolver este estudo, com o fito de ressignificar e contribuir para a representação da Enfermagem na sociedade, e delinear a identidade profissional da enfermeira, no presente caso, a enfermeira que atua como gestora no Programa IDA. 